\title{
PENGARUH ORGANISASI KEPRAMUKAAN TERHADAP KEMAMPUAN MENYAMPAIKAN PENDAPAT MAHASISWA
}

\author{
Diantini $^{1}$, Nadya Putri Saylendra ${ }^{2}$, Tridays Repelita ${ }^{3}$ \\ pk16.diantini@mhs.ubpkarawang.ac.id ${ }^{1}$ \\ nadya.saylendra@ubpkarawang.ac.id ${ }^{2}$ \\ tridays.repelita@ubpkarawang.ac.id ${ }^{3}$
}

\begin{abstract}
This research was conducted on the basis of the researcher's anxiety related to the low students' ability to convey their opinions in public. The method used of this research was quantitative using correlational analysis. The stages in this research are instrument testing, data collection, data analysis, and data interpretation. The research population was the members of the scouting organization at the University of Buana Perjuangan Karawang. The data collection technique used was probability sampling with simple linear regression analysis techniques. From the research results obtained that $\left(\mathrm{t}_{\text {count }}=5.424>\mathrm{t}_{\text {table }}\right.$ $=2.042 ; \mathrm{p}$ value $=0.00<0.05)$. These results indicate that the hypothesis that there is a significant influence between scouting organization on the ability to convey students' opinions $\left(\mathrm{H}_{1}\right)$ is accepted. It can be concluded that $51.2 \%$ of the scouting organizational factors affect the ability to convey students' opinions. The recommendations from this study, it is suggested that students carry out their duties as well as possible with the hope of being able to motivate themselves, explore knowledge and experiences to face the real life outside the campus and and the policy makers are expected to appreciate all forms of students' potential, including their ability to express opinions.
\end{abstract}

Keywords: Student Organization, Scout, Expressing opinions

\begin{abstract}
ABSTRAK
Penelitian ini dilakukan atas dasar kegelisahan peneliti terkait dengan rendahnya kemampuan menyampaikan pendapat mahasiswa di depan umum. Metode yang digunakan dalam penelitian ini adalah kuantitatif dengan menggunakan analisis korelasional. Tahapan dalam penelitian ini yaitu uji instrumen, pengumpulan data, menganalisa data, serta menginterpretasikan data. Populasi penelitian adalah anggota organisasi kepramukaan Universitas Buana Perjuangan Karawang dengan teknik pengumpulan data yang digunakan adalah probability sampling dengan teknis analisis regresi linier sederhana. Dari hasil penelitian diperoleh ( $\mathrm{t}_{\text {hitung }}=5.424>\mathrm{t}_{\text {tabel }}=2.042 ; \mathrm{p}$ value $=0,00<0,05$ ) hasil tersebut menunjukkan bahwa hipotesis terdapat pengaruh yang signifikan antara organisasi kepramukaan terhadap kemampuan menyampaikan pendapat mahasiswa $\left(\mathrm{H}_{1}\right)$ diterima. Dapat disimpulkan bahwa sebesar 51,2\% faktor organisasi kepramukaan mempengaruhi kemampuan menyampaikan pendapat mahasiswa. Rekomendasi dari penelitian ini, disarankan agar mahasiswa melaksanakan tugas sabaikbaiknya dengan harapan mampu memotivasi diri, mengeksplor pengetahuan dan pengalaman untuk kehidupan nyata di luar kampus dan pemangku kebijakan lebih mengapresiasi segala bentuk potensi mahasiswa termasuk kemampuannya dalam menyampaikan pendapat.
\end{abstract}

Kata kunci: Organisasi Mahasiswa, Pramuka, Menyampaikan Pendapat 


\section{PENDAHULUAN}

Pada era perkembangan zaman dan persaingan dunia saat ini, seluruh negara dituntut untuk bisa bersaing, bukan hanya negara akan tetapi setiap orang harus berusaha menunjukkan kemampuan dan keunggulannya sebagai salah satu sumber daya untuk menghadapi persaingan. Globalisasi membuat setiap orang berhadapan dengan kompetisi yang semakin tajam. Tantangan terberat yang dihadapi oleh perguruan tinggi yaitu dituntut untuk mampu menghadirkan lulusan yang intelek, berkualitas, dan berkompetensi. Upaya tersebut diwujudkan dengan adanya pendidikan yang tercantum pada Undang-Undang RI No. 20 tahun 2003 yang berisi bahwa :

"Pendidikan adalah usaha sadar dan terencana untuk mewujudkan suasana belajar dan proses pembelajaran agar peserta didik secara aktif mengembangkan potensi dirinya untuk memiliki kekuatan spiritual keagamaan, pengendalian diri, kepribadian, kecerdasan, akhlak mulia, serta keterampilan yang diperlukan dirinya, masyarakat, bangsa, dan negara."

Aturan ini berkesinambungan dengan tujuan untuk mencetak manusia-manusia yang lebih baik dari waktu ke waktu. Adapun dalam pasal 1 Undang-Undang Sistem Pendidikan Nasional No. 20 tahun 2003 menyatakan "Sistem Pendidikan Nasional adalah keseluruhan komponen pendidikan yang saling terkait secara terpadu untuk mencapai tujuan pendidikan nasional". Sedangkan tujuan pendidikan nasional tidak lepas dari tercetaknya manusia-manusia yang berkualitas sesuai dengan Undang-Undang Pendidikan Nasional No. 20 tahun 2003 yang berisi:

"Pendidikan bertujuan untuk berkembangnya potensi pesrta didik agar menjadi manusia yang beriman dan bertakwa kepada Tuhan Yang Maha Esa, berakhlak mulia, sehat, berilmu, cakap, kreatif, mandiri, dan menjadi warga negara yang demokratis serta bertanggung jawab".

Proses belajar yang dilakukan dalam ranah perguruan tinggi bukan hanya pembelajaran di dalam kelas, akan tetapi juga pembelajaran dalam organisasi kemahasiswaan. Mahasiswa dituntut untuk memiliki kemampuan berpikir, bernalar, dan termasuk kemampuan untuk menyampaikan pendapat. berorganisasi menjadi salah satu tempat untuk mengeksplorasi pengetahuan dan mengembangkan kemampuan mahasiswa.

Mahasiswa dalam pandangan umum dinilai sebagai pribadi yang memiliki kecerdasan dan salah satu bagian dari agen perubahan. Akan tetapi kecerdasan bukan hanya satu-satunya hal yang bisa menciptakan perubahan, hal tersebut harus diimbangi dengan kemampuan mengkomunikasikan ide atau gagasan kepada orang lain. Sesuai dengan pernyataan Idrus 
(2009:71) yang berpendapat : “seseorang memiliki kecerdasan, bukan karena yang bersangkutan memiliki kemampuan untuk mengelaborasi masalah dari persoalan yang dihadapi, tetapi jika yang bersangkutan memiliki kemampuan untuk berkomunikasi kepada orang lain".

Kemampuan menyampaikan pendapat mahasiswa dipengaruhi oleh pengetahuan, wawasan, latar belakang pengetahuan, ataupun pengalaman yang telah seseorang dapatkan. Adapun salah satu aspek yang mempengaruhi kemampuan menyampaikan pendapat mahasiswa diantaranya kegiatan berorganisasi di lingkungan kampus.

Organisasi kepramukaan merupakan salah satu organisasi kepemudaan yang berfungsi sebagai wadah pengembangan diri. Dalam Sesuai dengan Keputusan Presiden No. 238 Tahun 1996 bahwa "Gerakan Pramuka adalah perkumpulan gerakan pendidikan kepanduan kebangsaan Indonesia untuk anak-anak dan pemuda warga negara Republik Indonesia" yang bertujuan untuk mencetak pemuda dan anak-anak Indonesia agar mereka hadir sebagai manusia yang meiliki watak, kepribadian, budi pekerti yang luhur, bertakwa, bermental dan bermoral baik, memiliki kecerdasan dan keterampilan, serta sehat tubuhnya. Sehingga melalui tujuan organisasi kepramukaan ini kemampuan mahasiswa dalam meningkatkan keterampilan berkomunikasi dapat terlatih sehingga berefek terhadap kemampuan mahasiswa dalam menyampaikan pendapat.

Melalui berbagai hal yang telah dijelaskan diatas, maka dilakukanlah penelitian untuk mengetahui pengaruh organisasi kepramukaan terhadap kemampuan menyampaikan pendapat mahasiswa.

\section{METODE PENELITIAN}

Penelitian ini dilakukan di Organisasi Kepramukaan Universitas Buana Perjuangan Karawang pada semester genap bulan Maret-Mei 2020. Penelitian ini termasuk kedalam jenis penelitian kuantitatif dengan pendekatan analisis korelasional. Tahapan dalam penelitian ini yaitu uji instrumen, pengumpulan data, menganalisa data, serta menginterpretasikan data. Proses pengumpulan data utama dilakukan dengan kuesioner yaitu membuat serangkaian pertanyaan untuk memperoleh data. Teknik sampling dalam penelitian ini yaitu probability sampling. Selanjutnya dilakukan analisis data dengan teknis analisis regresi linier sederhana yang meliputi uji koefisisen korelasi, uji koefisien determinasi dan uji signifikansi untuk menguji hipotesis dan penarikan kesimpulan. 


\section{HASIL PENELITIAN DAN PEMBAHASAN}

Penelitian ini dilakukan dengan analisis regresi linier untuk mengetahui keterkaitan antara organisasi kepramukaan terhadap kemampuan menyampaikan pendapat. Adapun teknik sampling yang digunakan dalam penelitian ini yaitu probability sampling yang berarti bahwa seluruh anggota populasi diberikan kesempatan yang sama untuk menjadi anggota sampel.

Berdasarkan hasil penelitian yang dilakukan, dapat diketahui bahwa besaran nilai koefisien korelasi adalah 0,716 yang mengandung arti tingkat hubungan (korelasi) antara organisasi kepramukaan terhadap kemampuan menyampaikan pendapat mahasiswa adalah korelasi yang kuat. Untuk arah korelasi antara organisasi kepramukaan terhadap kemampuan menyampaikan pendapat mahasiswa memiliki hubungan secara positif. Pada Uji Signifikansi (Uji T) Variabel bebas terhadap variabel terikat nilai thitung $(5,424)$ lebih besar dari pada nilai ttabel $(2,042)$ dengan penggunaan taraf signifikan 0,05 jatuh atau berada di daerah penerimaan $\mathrm{H} 1$ yang menunjukkan adanya pengaruh organisasi kepramukaan terhadap kemampuan menyampaikan pendapat mahasiswa. Berikut hasil uji T pada penelitian ini.

\begin{tabular}{|c|c|c|c|c|c|c|}
\hline \multicolumn{7}{|c|}{ Coefficients $^{a}$} \\
\hline \multirow{2}{*}{\multicolumn{2}{|c|}{ Model }} & \multicolumn{2}{|c|}{$\begin{array}{l}\text { Unstandardized } \\
\text { Coefficients }\end{array}$} & \multirow{2}{*}{$\begin{array}{l}\text { Standardized } \\
\text { Coefficients } \\
\text { Beta }\end{array}$} & \multirow{2}{*}{$\mathrm{t}$} & \multirow{2}{*}{ Sig. } \\
\hline & & B & Std. Error & & & \\
\hline \multirow[t]{2}{*}{1} & (Constant) & 8.844 & 8.282 & & 1.068 & 0.295 \\
\hline & $\begin{array}{l}\text { Pengaruh } \\
\text { Organisasi } \\
\text { Kepramukaan }\end{array}$ & 0.679 & 0.125 & 0.716 & 5.424 & 0.000 \\
\hline
\end{tabular}

a. Dependent Variable: Kemampuan Menyampaikan Pendapat Mahasiswa

Tingkat korelasi dan kekuatan hubungan yang cukup serta memenuhi indikator kemampuan menyampaikan pendapat yang baik seperti kelancaran berbicara dan memahami apa yang disampaikan. Sesuai dengan indikator menyampaikan pendapat menurut (Romdiyatun, 2012 hlm15) yang terdiri dari (1) Kejelasan berpendapat, (2) Kemampuan mengkomunikasikan pendapat, (3) Isi gagasan dan (4) Keruntutan ide. Pemenuhan indikator tersebut dapat diketahui dari data yang telah dikumpulkan. Pemenuhan indikator tersebut dapat diketahui dari data yang telah dikumpulkan bahwa responden yang mengikuti organisasi kemahasiswaan sudah cukup memenuhi indikator-indikator kemampuan menyampaikan pendapat. Selain itu, menurut (Utami, $2009 \mathrm{hlm}$ 34) indikator mengemukakan pendapat antara lain: (1) Respon yang dipilih, (2) Logat bicara, (3) Kosakata, (4) Keberanian, (5) Kelancaran, 
(6) Etika penyampaian pendapat, dan (7) Kesesuaian pendapat dengan topik pembicaraan. Dari data yang diperoleh, organisasi kepramukaan melatih anggotanya untuk terbiasa berani dalam menyampaikan pendapat saat berdiskusi, memilih respon yang baik dengan lawan bicara, menanggalkan logat bicara daerahnya dan menggunakan kosa kata yang tidak berbelit-belit saat menyampaikan pendapatnya.

Untuk arah korelasi antara organisasi kepramukaan terhadap kemampuan menyampaikan pendapat mahasiswa memiliki hubungan kausal yang positif. Positif disini mengandung arti bahwa hubungan antara variabel bebas dan variabel terikat bersifat searah, artinya semakin tinggi tingkat pengaruh organisasi kepramukaan maka kemampuan menyampaikan pendapat mahasiswa akan meningkat. Peran organisasi kepramukaan cukup mengasah kemampuan menyampaikan pendapat mahasiswa sehingga pengaruhnya mencapai 51,2\% sedangkan 48,8\% nya dipengaruhi oleh hal-hal lain diluar organisasi kepramukaan. Dari hasil uji model keseluruhan dapat diketahui juga Fhitung > Ftabel $(29,418>4,17)$. Dengan nilai signifikansi $0,00<0,05$ pada table berikut:

\begin{tabular}{|c|c|c|c|c|c|c|}
\hline \multicolumn{7}{|c|}{ ANOVA $^{\mathrm{a}}$} \\
\hline \multicolumn{2}{|c|}{ Model } & $\begin{array}{c}\text { Sum of } \\
\text { Squares }\end{array}$ & Df & $\begin{array}{c}\text { Mean } \\
\text { Square }\end{array}$ & $\mathrm{F}$ & Sig. \\
\hline 1 & Regression & 534.566 & 1 & 534.566 & 29.418 & $.000^{\mathrm{b}}$ \\
& Residual & 508.800 & 28 & & & \\
& Total & 1043.367 & 29 & 18.171 & & \\
& & & & & \\
\end{tabular}

a. Dependent Variable: Kemampuan Menyampaikan Pendapat Mahasiswa

b. Predictors: (Constant), Pengaruh Organisasi Kepramukaan

Kemampuan mengemukakan pendapat dapat diasah dan dilatih melalui berbagai hal diantaranya bagaimana cara berbicara dalam menyampaikan pendapat, sikap sebelum dan sesudah menyampaikan pendapat, maupun keberanian dalam menyampaikan pendapat (Novianawati, 2016 hlm 5). Sejalan dengan penjelasan tersebut, keberadaan organisasi kepramukaan mampu melatih kemampuan menyampaikan pendapat melalui cara, sikap dan keberanian menyampaikan pendapat terutama didepan umum.

Dikaitkan dengan organisasi kepramukaan ini tentu Dasa Darma bukan hanya sekedar barisan nilai-nilai pembentuk kepribadian tetapi juga harus mampu diterapkan dalam aspek kehidupan yang nyata erat kaitannya dengan Dasa Darma ke-8 yang berisi “jujur, berani, dan setia" ditegaskan bahwa setiap anggota kepramukaan harus memiliki sikap keberanian. Diperkuat dengan Dasa Darma ke-10 yang berisi "suci dalam pikiran, perkataan, dan perbuatan" yang jika dikaitkan dengan pilar sebelumnya bahwa karakter yang ditanamakan 
dalam diri setiap anggota kepramukaan harus berani dalam segala hal meliputi keberanian menyalurkan ide yang menjadi pikiran atau gagasannya dengan perkataan dan perbuatan yang baik.

\section{KESIMPULAN}

Hasil penelitian ini memberikan gambaran bahwa kemampuan menyampaikan pendapat mahasiswa dapat dipengaruhi oleh beberapa faktor eksternal, satu diantaranya adalah keikutsertaan mahasiswa dalam organisasi termasuk organisasi kepramukaan. Dalam hal ini pelaksanaan mahasiswa dalam menyampaikan pendapat baik di dalam forum formal ataupun non formal dapat dipengaruhi karena keaktifan seorang mahasiswa yang terbiasa menyampaikan pendapat di dalam berorganisasi. Beberapa aspek yang membuat rendahnya minat mahasiswa dalam menyampaikan pendapat adalah rendahnya keinginan dalam menyampaikan gagasan, rasa takut menyampaikan pendapatnya di depan umum dan kurangnya wawasan ataupun pengetahuan yang dimiliki mahasiswa untuk dapat menyampaikan pendapat secara baik dan benar. Organisasi dinilai berkontribusi dalam meningkatkan potensi mahasiswa terutama dalam kemapuan menyampaikan pendapat nampak jelas menjadikan mahasiswa mampu bertasnggung jawab dan memiliki kepercayaan diri untuk mengungkapkan apa yang menjadi gagasan serta pendapatnya di muka umum.

\section{DAFTAR PUSTAKA}

Idrus, M. 2009. Metode penelitian Ilmu Sosial. Yogyakarta: PT. Gelora Akasara.

Keputusan Presiden Republik Indonesia No. 238 Tahun 1961 tentang Gerakan Pramuka

Novianawati, Selvilias. 2016. Upaya Meningkatkan Keterampilan MengemukakanPendapat Siswa Melalui Metode Time Token” Skripsi, Universitas Pasundan, Pasundan.

Romdiyatun, Siti. 2012. Upaya Meningkatkan Kemampuan Mengemukakan PendapatKepada Orang Lain Melalui Metode Sosiodrama pada Anak Kelompok B di TK ABA Manjungan Klaten Tahun 2011/2012. Skripsi. FKIP UMS.

Sugiyono. 2014. Metode Penelitian Kuantitatif Kualitatif dan R\&D. Bandung: Alfabeta.

Undang-Undang RI No. 20 tahun 2003 tentang Sistem Pendidikan Nasional.

Utami, Munandar. 2009. Pengembangan Kreativitas Anak berbakat. Jakarta: Rineka Cipta. 